DOI:10.24193/tras.54E.1

Published First Online: 2018/06/29

\title{
THE MAGIC SHOES OF IPSAS: WILL THEY FIT TURKEY?
}

\author{
Selver Seda ADA \\ Johan CHRISTIAENS
}

Selver Seda ADA (Corresponding author)

PhD Researcher, Department of Public Governance, Management and Finance, Faculty of Economics and Business Administration, Ghent University, Ghent, Belgium Tel.: 0032-09-264.3540

E-mail: selverseda.ada@ugent.be

\section{Johan CHRISTIAENS}

Professor, Department of Public Governance, Management and

Abstract

In this study, we seek to further delineate the reasons for the existence of shortfalls in the level of formal and material harmonization regarding the accrual-based rules in International Public Sector Accounting Standards (IPSAS) by analyzing the law, the executive order and the Turkish Central Government Public Reports from 2010 to 2014 (using a mixed method approach). We highlight that coercive pressure itself is insufficient for improving substantive performance and changing the internal structures of organizations, instead, such pressures cause decoupling in financial reporting.

As a new finding in the context of a developing country, we suggest that there are several discrepancies between the law and the executive order. Moreover, we conclude that there are emerging country-specific reasons affecting the gap in the harmonization levels, including a lack of social pressure which tends to be prominent in developed countries, state domination over both civic matters and the private sector, and translation problems that arise during the adoption process.

Keywords: harmonization, IPSAS, Turkey, public sector, accounting.

Finance, Faculty of Economics and Business Administration, Ghent University, Ghent, Belgium

Tel.: 0032-09-264.3540

E-mail: johan.christiaens@ugent.be 


\section{Introduction}

The implementation of policies and techniques associated with accrual accounting is understood to be a crucial factor in modernizing the public sector in developing countries (Antipova and Bourmistrov, 2013, p. 444) and IPSAS has been considered a point of departure for streamlining central governments to improve transparency and accountability (Hughes, 2013).

International Public Sector Accounting Standards (IPSAS) based accrual accounting standards have been well established in most of the OECD countries, and $50 \%$ of non-OECD countries have expressed an intention to adopt accrual accounting, often using IPSAS as a reference point (Alshujairi, 2014, p. 1). However, Deaconu, Nistor and Filip (2011, p. 76) suggest that emerging countries have too eagerly accepted the transition from cash-based accounting to accrual-based accounting, and argue that emerging countries seem to have taken it for granted that adopting accrual-based rules will increase efficiency and effectiveness and solve many of the problems in their traditional accounting systems. Studies have demonstrated that 'variation in accounting are still an essential characteristic of governmental financial reporting' (Antipova and Bourmistrov, 2013, p. 443) even in countries in which Government Financial Statistics (GFS) and IPSAS have been adopted.

Several studies have uncovered evidence regarding various aspects of the adoption and implementation of accrual accounting in the public sector, such as ambiguities in the implementation process and the relationship between central and local governments (Arnaboldi and Lapsley, 2009, p. 809), loose coupling and substantial resistance during the implementation process (Nor-Azizah and Scapens, 2007, p. 209), cost efficiencies associated with accrual accounting (Lampe, Hilgers and Ihl, 2015) and habitual and technical factors associated with adopting accrual accounting (Connolly and Hyndman, 2006, p. 272; Rahaman, 2009, p. 224). Other studies have conducted international comparisons regarding the adoption of IPSAS (Benito, Brusca and Montesinos, 2007, p. 293; Christiaens et al., 2015, p. 158; Christiaens, Reyniers and Rolle, 2010; Pina, Torres and Yetano, 2009, p. 765; Pina and Torres, 2003, p. 334). However, research concerning developing countries and transitional economies adopting and implementing accrual accounting has only begun and has primarily focused on a limited number of country-specific cases involving IPSAS standards adoption (Deaconu, Nistor and Filip, 2011, p. 74; Gomes, Fernandes and Carvalho, 2015, p. 268; Oulasvirta, 2014, p. 272). Most of the studies have demonstrated that failure in the disclosure level of the financial reporting is caused by numerous problems that arise during the implementation process (Allen and Sanders, 1994; Ryan, Stanley and Nelson, 2002; Pina and Torres, 2003; Giroux and McLelland, 2003; Coy and Dixon, 2004; Tooley and Guthrie, 2007; Benito, Brusca and Montesinos, 2007).

Accordingly, several hypotheses have been formulated to emphasize the problems causing a gap between the executive order (the regulations that are needed to implement the law) and the daily practices, which is also called material harmonization. However little attention has been given thus far to formal harmonization, the 
gap between the law and the executive order. Therefore, apart from the gap between the executive order and the daily practices (material harmonization) insights into the gap between the executive order and the law (formal harmonization) could be an important factor for the success of the accrual accounting adoption and thus implementation. Hence, this study is designed as follows: we use a mixed-method approach (Tashakkori and Teddlie, 1998) in order to improve our understanding of where and why the adoption and implementation of accrual accounting in the public sector fails.

First, we use a table derived from the disclosure items (Benito, Brusca and Montesinos, 2007, p. 303) to calculate the formal and material harmonization level as a means to determine the reasons for shortfalls. In the context of our research, (a) the Public Financial Management Control Law (PFMCL) represents the law that is in line with IPSAS; (b) the General Management Accounting Regulation (GMAR) is the executive order as the operationalization regulation of PFMCL; and (c) the Central Government Public Report represents the actual practices after the implementation of the executive order (please see Figure 1). We consider the gaps between (a) and (b) and between (a) and (c).

Secondly, because the aim of this paper is to shed light on the reasons for the shortfalls in the harmonization levels, we conduct semi-structured interviews with key public sector actors (see Table 1) to explain the reasons for shortfalls in the adoption and implementation of accrual-based rules. We use institutional theory and the decoupling concept to develop possible explanations for the gap with IPSAS. In light of these research questions, we examine Turkey, which does not fit squarely into either Europe or the Middle East (Müftüler Bac, 2005, p. 18). Similar to many emerging countries, despite the implementation of accrual accounting rules more than ten years ago in the Turkish public accounting sector, there are still shortfalls in the formal and material harmonization levels.

This paper addresses a gap in the literature identified by Gomes, Fernandes and Carvalho (2015, p. 269), Marti and Kaperskaya (2015, p. 177), and Ouslavista (2014, p. 274) regarding the lack of research on country-specific cases involving IPSAS. As a contribution, we reveal that the difference between the law and the executive order has been created intentionally as a way to avoid changes in the internal structures of organizations. Second, in accordance with Andrews (2012, p. 137), this study is a good source of data to deepen our understanding of possible failures in the actual practices of implementing formal rules in an emerging country in order to identify relevant practices for emerging countries instead of best practices. The remainder of this paper is structured as follows: Section 2 addresses the theoretical framework. The research questions and methodology are then followed by a presentation of the level of disclosure and discussion. The final section presents our conclusion.

\section{Theoretical framework}

The rational motive behind several countries' decision to adopt the accrual accounting method is a common institutional theory, which is one of the major theo- 
retical approaches in public sector accounting research (Van Helden, 2005, p. 108). DiMaggio and Powell (1983, p. 150) identify three mechanisms for institutional isomorphic change: coercive, mimetic and normative isomorphism.

Coercive isomorphism arises from political influence and relates to the problem of legitimacy; it is characterized by the imposition of rules to adopt similar forms of change in both structures and processes. An important political concern at the national level may result in the implementation of IPSAS (Oulasvirta, 2014, p. 274), and because Turkey regards the EU as a benchmark, its concerns are Turkey's main motivation for the change in the public sector accounting. Turkey currently enjoys financial and technical support from international bodies such as the IMF, the EU, and the $\mathrm{WB}$, and one of the requirements for this continued support is the presentation of transparent and accountable financial statements consistent with the international standards. Thus, inspired by international standards, the Public Financial Management and Control Law no. 5018/2004 was introduced by the Turkish government to provide accountability and transparency to encourage the effective, economical and efficient distribution of public resources (in the form of coercive isomorphism). This accrual-based accounting regulation applies to public institutions, including the central government, local governments and social security institutions, through regulations based on the law, including the General Management Administrative Regulation, which is intended for application by the general management of the public sector in Turkey.

Mimetic isomorphism results from standard responses to uncertainty, and involves adopting changes that have been previously undertaken by other organizations. Reluctant organizations attempt to reorganize themselves in the likeness of organizations that they perceive as legitimate (DiMaggio and Powell, 1983, p. 152). Normative isomorphism, which is associated with professionalism, refers to the strong effects and pressures associated with professional affiliations. The influence of IFAC and IPSASB are examples of normative forces pressing for the adoption of IPSAS (Gomes, Fernandes and Carvalho, 2015, p. 272). These isomorphic processes cause organizations to become similar to one another, thus facilitating inter-organizational transactions. Although the three mechanisms may emerge under different conditions and have different outcomes, they tend to 'intermingle in an empirical setting' (DiMaggio and Powell, 1991, p. 67). Notwithstanding the fact that each mechanism involves a separate process, two or more isomorphic pressures can operate simultaneously, and clearly identifying the effects of each type of pressure is difficult in such situations.

Although these processes increase an organization's legitimacy, they also conflict with day-to-day activities (Nor-Azizah and Scapens, 2007, p. 213) in practice. Because of this incongruity between institutional pressures and an organization's exertions, institutional theorists argue that formal structures and actual operations of the formal structures often become 'decoupled' (DiMaggio and Powell, 1991, p. 67; Nor-Azizah and Scapens, 2007, p. 213; Bromley and Powell, 2012). Decoupling is described as a gap between policy and practice that protects the technical core and the internal 
structures of an organization (Nor-Azizah and Scapens, 2007, p. 213). According to Weick (1982, p. 360), decoupling is seen in situations in which elements affect one another 'suddenly (rather than continuously), occasionally (rather than constantly), negligibly (rather than significantly), indirectly (rather than directly), and eventually (rather than immediately)'. Based on this background, Bromley and Powell (2012) develop two types of decoupling and argue that decoupling occurs on two levels: 'policy and practice' and 'means and ends'. In the policy and practice type of decoupling, organizations adopt policies but do not implement them; this form of decoupling is likely to be seen as an operational failure. In means and ends decoupling, rules and policies are implemented but they have only a weak relationship with the intended goals (Bromley and Powell, 2012: p. 485); this form of decoupling is increasingly common in contemporary organizations (Bromley and Powell, 2012, p. 491). Based on this background, in this study, we borrow ideas from the concept of decoupling to explain the gap with IPSAS.

\section{Research questions and methodology}

The concept of harmonization is studied from different perspectives and within different contexts in the literature. Empirical research analyzing international harmonization primarily falls into one of two major approaches: (1) studies examining accounting standards and other regulations (formal harmonization), and (2) studies analyzing the accounting practices of entities within a given regulatory framework (material harmonization) (Tudor, 2010, p. 424); formal harmonization is the path and basis from which to achieve material harmonization (Tudor, 2010, p. 424). However, little research has examined both the formal and material harmonization of public accounting rules (Pina and Torres, 2003; Torres, 2004; Perez and Hernandez, 2007). Against this background, we consider the following research questions:

1.a. To what extent are the rules adopted by emerging countries (e.g., Turkish public accounting executive orders) consistent with IPSAS (formal harmonization) in terms of disclosures in financial reporting?

2.b. To what extent are the actual practices of implementing Turkish public accounting executive orders consistent with IPSAS (material harmonization) in terms of disclosures in financial reporting?

2. What explains the gap between IPSAS and the levels of harmonization (both formal and material) in terms of disclosure items?

We concentrate on Turkey as a striking case mainly owing to its demonstration capacity for other emerging country contexts (Öniş and Kutlay, 2016, p. 7). First, Turkey is an emerging country with rapid economic growth and an intense democratization experience, and it is a strong practitioner of the public sector reforms. Second, Turkish political elites became very ambitious in implementing public reforms during the first stage of the era of Justice and Development Party (AKP) from 2007 to 2011. Third, Turkey is a significant case for emerging countries not only because of its 
increasing capacity and political willingness for the implementation of reforms in the public sector but also for its failures, regressions and decline in AKP's performance which caused the gap between the goals and results as of 2012.

To answer the first research question, we used a table (please see Appendix 1) that includes the minimum requirements and crucial items for IPSAS regarding disclosure items, in line with the studies by Perez and Hernandez (2007, p. 152) and Benito, Brusca and Montesinos (2007, p. 303). This table (Appendix 1) consists of items and statements that provide various types of information related to budgets, physical assets, the depreciation of physical assets, accounting for borrowing costs, events occurring after the balance sheet date, statements of accounting policies, statements of differences in financial positions, contingencies, financial leasing operations, financial statement disclosures, consolidated financial statements, the cost of services, and the effective, economical and efficient distribution of resources (Benito, Brusca and Montesinos, 2007, p. 303; Perez and Hernandez, 2007, p. 152) to be disclosed in annual accounts under IPSAS. Because none of the items has priority over others and the items to be disclosed are regulated by law, we chose to evaluate the items dichotomously (i.e., as 1 for disclosed items and 0 for undisclosed items).

We analyzed the year-end Central Government Public Account Reports between 2010 and 2014. Owing to the national anti-corruption law that has been adopted in 2010, we selected the period from 2010 to 2014, to ensure that all financial reports have been reported under the same requirements. We also covered both periods mentioned above.

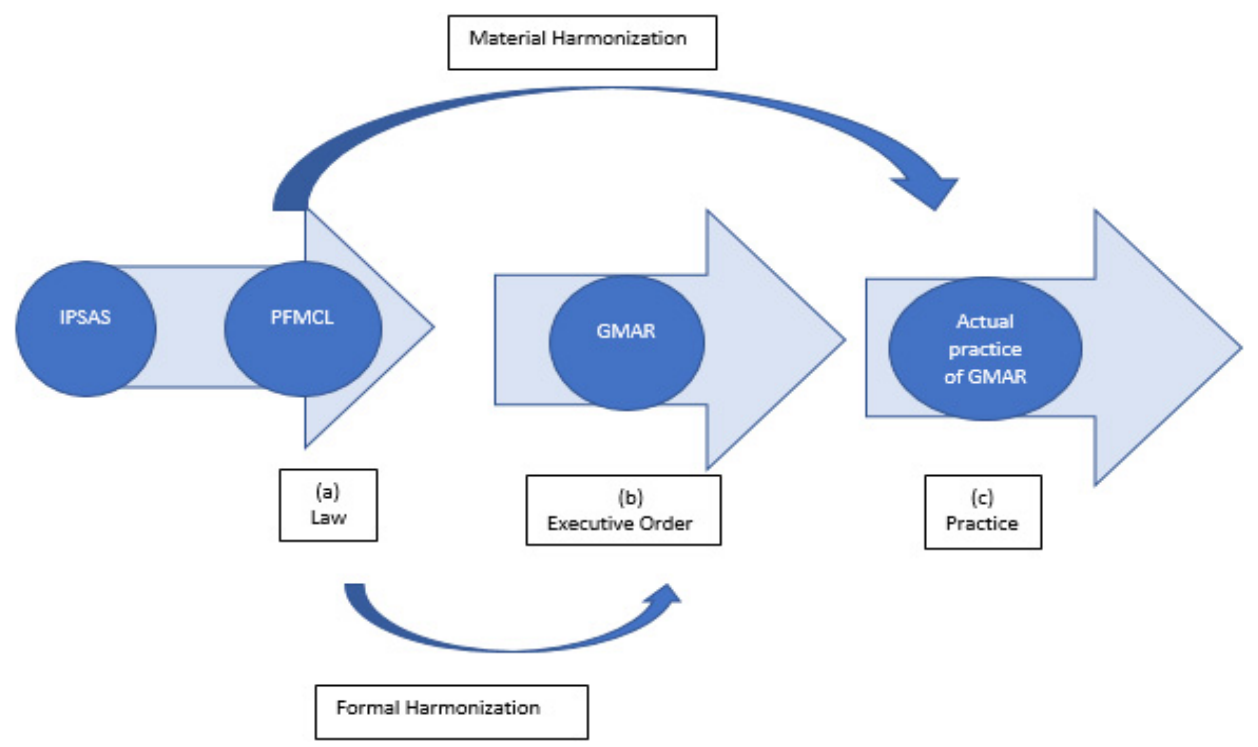

Note: IPSAS = International Public Sector Accounting Standards; PFMCL = Public Financial Management Control Law; GMAR = General Management Accounting Regulation.

Figure 1: The quantitative part of the study 
Second, in the qualitative part of the research, in order to interpret the results of the table and explain the differences between the executive order and actual practices under IPSAS, we conducted semi-structured interviews (please see Appendix 2) with key experts so that we could gain insights into their perceptions (Atkinson and Shaffir, 1998, p. 48). In other words, our research design provided us with a more complete understanding of the decoupling problems which arise during the implementation process from different perspectives. It is acknowledged that the interviews as a source of data are subject to the interviewees' accuracy, biases and motivations; we interviewed individuals with different types of roles, as proposed by Christensen and Parker (2010), such as: users of the information, producers of the information, promoters of the change, and commenters of the change such that we could avoid problems that may arise during the interviews as much as possible.

The selection of the interviewees was based on the expertise area (public sector finance) of the interviewees, and advice from the other interviewees. We checked how the opinions of the interviewees are representative and relevant as a group. Then we found that the interviewees had overlapping opinions. The interviews were conducted in different sessions between May 2013 and February 2017 and lasted approximately 60 minutes each (see Table 1). All but four of the interviews occurred face-toface; four interviews were performed via Skype.

Table 1: Overview of the interviews

\begin{tabular}{clllc}
\hline $\begin{array}{c}\text { Abbreviation } \\
\text { for the interviewee }\end{array}$ & Organization & \multicolumn{1}{c}{$\begin{array}{c}\text { Function } \\
\text { of the Interviewee }\end{array}$} & \multicolumn{1}{c}{$\begin{array}{c}\text { Responsibility } \\
\text { of the interviewee }\end{array}$} & $\begin{array}{c}\text { Interview } \\
\text { duration } \\
\text { (minutes) }\end{array}$ \\
\hline WB_1 & World Bank & Lead Specialist & Public Sector Financial Management & 54 \\
WB_2 & World Bank & Senior Specialist & Public Sector Financial Management & 52 \\
WB_3 & World Bank & Senior Specialist & Public Sector Financial Management & 62 \\
F_1 & Ministry of Finance & Manager & Public Accounts & 102 \\
F_2 & Ministry of Finance & Specialist & Public Accounts & 34 \\
F_3 & Ministry of Finance & Specialist & Public Accounts & 37 \\
CA_1 & Court of Accounts & Senior Specialist & External Audit & 64 \\
CA_2 & Court of Accounts & Senior Specialist & External Audit & 43 \\
CA_3 & Court of Accounts & Senior Specialist & External Audit & 40 \\
U_1 & University & Associate Professor & Public Sector & 42 \\
U_2 & University & Associate Professor & Public Sector Financial Management & 61 \\
U_3 & University & Full Professor & Public Sector & 83 \\
\hline
\end{tabular}

Source: The authors

\section{The level of disclosure}

The results (see Appendix 1) reveal a mean of $58 \%$ for the level of formal harmonization of the disclosure items in the executive order and a mean of $38 \%$ for the level of material harmonization for items disclosed in the Central Government Public Ac- 
counts from 2010 to 2014. Our consistent findings between 2010 and 2014 show that the most neglected items in terms of formal harmonization were those related to the disclosure of business-like items such as consolidation, financial leasing, and contingencies. However, in terms of material harmonization, the most neglected items were related to the disclosure of costs of services and the effective economic, and efficient distribution of resources. Because shortfalls in the levels of material harmonization also included shortfalls in formal harmonization, we consider the level of material harmonization to be explanatory. We mainly focus on disclosure items because disclosing information regarding outputs of the public sector is particularly important for ensuring control of the public sector by stakeholders. The relationship between disclosure and accountability is not robust for all forms of disclosure. Instead of conflating transparency and accountability, we must identify the conditions under which information disclosure actually boosts accountability (Nelson, 2003, p. 250).

We begin our analysis with the budget-related items disclosed in the Central Government Public Accounts. The highest disclosure level is $87.5 \%$ for the budgetary information items; all budget items, including the functional, economic, corporate and financial classification of budget items, have been disclosed properly. This result, indicating proper disclosure may be based on the importance of budgetary items given the legal control of the budget in the Turkish governmental accounting context. In Turkey, as in other code law countries, the budget is used as a tool to exercise legal control (Manes Rossi, Aversano and Christiaens, 2014, p. 459).

Although IPSAS 1 does not establish indicators regarding the effective, economic, and efficient distribution of resources, it does provide recommendations. Analyzing the harmonization level of items related to the cost of services and the effective, economic, and efficient distribution of resources, we observe a disclosure level of $0 \%$. The reason for this gap may relate to the structure of the information, in stark contrast to international standards, such that detailed information is not a component of financial reports as described by the rules. By contrast, in Turkey, indicators of the cost of services and the effective, economic, and efficient distribution of resources are generally presented in organizational strategic performance reports. However, strategic performance reports are not an integral part of the annual reports. In addition, Turkish society may be disadvantaged by 'the lack of pre-conditions for an information society' (Kocack, 2003, p. 1). Moreover, we observe that Turkish regulations have only a few rules regarding information disclosure and even those few rules are applied only partially in the financial statements of the central government. These results provide important clues about accounting traditions in Turkey, as noted in our discussion section.

IPSAS 17 states the disclosures required for each class of property, plant and equipment. Whereas items regarding the disclosure of physical assets are neglected in the actual practices of the rules, items pertaining to the disclosure of the depreciation of physical assets are presented in the Central Government Public Accounts. The reason for this gap may be that information about the depreciation of physical assets 
is an important part of the executive order, but detailed information about physical assets (e.g., information on asset variation, intangible assets, and infrastructure assets) is not an integral part of the executive order. Based on the same logic, there are also many shortfalls in disclosures related to borrowing costs; the only item disclosed is the total borrowing cost.

Moreover, business-like items such as information about financial leasing operations and consolidated financial statements are not mentioned in any article in the executive order. Regarding financial leasing, IPSAS 13 specifies the details of disclosures for leases. In Turkey, even public institutions have the authority to engage in financial leasing, and leased items are not shown in the financial reports. Moreover, events occurring after balance dates are not disclosed in the actual practice of the formal rules. In fact, one article covers events occurring after the balance sheet date, but it is slightly different from that contained in IPSAS. In addition, statements regarding variation in the financial positions and information about contingencies are not disclosed in the actual practice of the formal rules.

Regarding accounting policies in the Turkish regulation, every entity is required to prospectively account for changes in accounting policies. Moreover, although changes in accounting estimates constitute an important part of IPSAS, they are not mentioned in any article of the executive order. In addition, IPSAS 3 describes the disclosure of changes in the accounting policies, changes in the accounting estimates and correction of errors. By contrast, when an error arises under the Turkish regulation, its correction is shown prospectively in the opening transactions of the next fiscal year.

Clearly, a significant amount of financial reporting information is disclosed, but further development is needed. Data that are considered a priority, such as infrastructure assets, depreciation, contingent liabilities, and information regarding effectiveness and efficiency that remains hidden may gradually be disclosed. After 10 years of implementation of accrual-based rules that are largely in harmony with the international rules, Turkey remains in an early stage of harmonization. The findings of the interviews are discussed in the discussion section.

\section{Discussion}

As a first explanation for the gap mainly in terms of formal harmonization, we observe 'the means and ends' (Bromley and Powell, 2012) type of decoupling in the Turkish setting in which the rules and policies are implemented with uncertain relations to outcomes. This implementation, even with its uncertain relation to outcomes, clearly increases the legitimacy of the related public sector in the eye of international bodies, as donor support is particularly involved with the improvements to the law. However, instead of being homogenous and similar, the heterogeneity continues in a more complicated way with irrelevant outcomes. This leads us to the finding stated by Ashworth, Boyne and Delbridge (2007, p. 165) that 'the primary objective of organizational change is not better substantive performance but greater legitimacy' in most developing countries, which is also observed in the Turkish case. One of the 
interviewees stated as follows: 'The accuracy of the figures in the financial statements is not as important as the figure itself' (F_1).

Even though the law is in line with the international standards (WB_1, WB_2, WB_3), there is a significant gap between IPSAS and the executive order. The gap in the executive order is being caused intentionally, instead of being an operational failure, in order to protect the technical core and the internal structures of the organizations from the external pressures (Bromley and Powell, 2012, p. 498). We observe that the coercive pressures of the international bodies may be a potent force in the decision to adopt accrual-based rules based on the central notion of legitimacy. However, coercive pressure itself is not sufficient to lead to successful adoption and implementation, and thus to improve the degree of transparency or the disclosure level. Coercive influences are limited in their ability to affect the core aspects of the organizations (Ashworth, Boyne and Delbridge, 2007) which are 'less likely to be visible and more likely to be protected from change' (Andrews, 2011) and causing decoupling. Moreover, instead of following the principles proposed by the law, the executive order is being used as a tool to protect the internal structures of the organizations as explained by the interviewee: 'Instead of following the requirements ordered by the law, they change the law and then 'de facto' applications become legitimized by passing according to the legislature' (WB_2). The interviewee WB_3 added the following: 'Turkish authorities know very well how to score high on assessments by international organizations. In this vein, evaluations generally pertain to whether or not a report has been published within the timeframe determined by a specific law, or whether or not certain topics are covered in the report. Turkish authorities publish the reports on the indicated/required date. This way evaluation criteria are met, but the content of the reports may be often laden with problems'.

Second, as an emerging country-specific explanation that deepens the gap in formal and material harmonization, changes in the Turkish public sector are rarely due to grassroots demand (F_1, F_2, U_1, WB_2) and the Turkish government does not face pressure from the society as in developed countries (Yüzyıl, 1996, p. 21). Concomitantly, items regarding information supplied to stakeholders are the most neglected aspect of Turkey's formal and material harmonization. In the Turkish context, the users of financial statements are not mentioned in any article of the executive order. Moreover, the statement 'the users of financial statements' is not found in either the executive order or the translated Turkish IPSAS; this may be a strong indication of the nature of the relationship between the state and the civil society.

In such a context, one might argue that the applicability of the reforms depends on public pressure and citizens' expectations. Apart from public pressure, internal audits and external audits should be operating well, and the legislature should be able to force the executive to apply the rules; however, such an enforcement mechanism does not work in Turkey (CA_1, U_1). The absence of an active media in informing society further hinders harmonization.

Third, in Turkey, the state dominates the private sector, in addition to civil society and this may be one of the reasons for the shortfall in the business-like items for both 
formal and material harmonization. Sözen and Shaw (2002, p. 482) explain the situation as follows: ' $\ldots$ the private sector is in a dependency relationship with the state. An indication of this is the way in which top Civil Servants transfer into the private sector. .... in the UK there is some degree of transfer of top managers from the private sector to government. This is almost unheard of in Turkey. As a consequence, in the UK a degree of private sector values enters the public sector, whereas in Turkey, it could be argued that public sector values enter the private sector'. In such a situation, 'introducing business-like items (e.g., financial leasing operations, consolidation methods) into public sector accounting is quite difficult' (WB_2, CA_1). This difficulty increases the buffer generated by decoupling.

Finally, critical problems arise during the translation of IPSAS concepts from English to Turkish that lead to the non-disclosure of certain items in the Turkish context with regard to formal harmonization (F_1, F_2, F_3). The problems lie in both the translations themselves and the understanding of certain concepts in cultures in which such concepts seem foreign (Zeff, 2007, p. 296). Such conceptual differences arise 'from the fact that the relationship between concepts and terms is far from univocal' (Marco, 2007, p. 265), which leads to differences between the source text and the target text as a result of difficulties finding suitable equivalents for accounting terms, as in the Turkish case. The solution to this problem is important for the application of a single set of accounting standards throughout the world.

\section{Conclusion}

Using institutional theory and the concept of decoupling, we argued that the change in the public sector accounting system in Turkey was primarily motivated by international organizations as a potent coercive force for the adoption of accrual-based rules. In Turkey's case, coercive pressures exerted by international bodies are clearly observed in the form of laws (such as PFMCL), which leads to increased legitimacy in the eyes of institutional bodies. However, as a striking finding of our study, we reveal that the executive order (GMAR), which was issued based on the law (PFMCL), to streamline the Turkish system under international pressure, has led to a decoupling, because intentional differences between the law and the executive order were created.

Changes in the accounting system appear to have been implemented primarily to benefit the Turkish government's image, particularly in the eyes of international bodies. In this sense, we suggest a crucial finding that without the destruction of the existing order and increased internal motivation, the pressure to change exerted by international bodies become a limitation in both the adoption and implementation processes. In such a context, as observed from the results, overall levels of harmonization regarding the disclosure items are relatively low ( $58 \%$ for formal harmonization and $38 \%$ for material harmonization), which may indicate that the reforms are somewhat behind the agenda of Turkey's central governments; hence, the magic shoes of IPSAS do not fit comfortably in the current context. Moreover, we emphasize emerging 
country-specific factors that deepen the gap in the level of harmonization, including a lack of social pressure which is generally more prominent in developed countries, and state domination over both civic matters and the private sector. In addition, this study emphasizes the importance of translating concepts in IPSAS from English into different national languages as a potential common problem in the IPSAS adoption process.

Although accrual accounting-based rules were implemented nearly ten years ago, central governments may need more time to internalize them, and we should consider whether central governments and local governments can truly incorporate the NPM style of thinking into their routines.

Furthermore, we must develop new ideas in order to translate IPSAS into public sector accounting behavior. It is not sufficient to formulate financial statements accurately; annual accounts and related information must be open to the public. In this aspect, information campaigns could target citizens to inform them about their rights to obtain information regarding government activities. Enforcement systems that seek to increase the level of disclosure may be useful for reaching sustainable institutional success. These results also offer some implications for policy making, especially for the disclosure items, for which the implementation of the IPSAS is critical. Bearing in mind the main ideas regarding the discrepancy between the law and the executive order, it seems quite critical to convince policy makers of the economy, efficiency and effectiveness of the accrual based standards for the success of the implementation. It is obvious that special attention should be paid to controlling the discrepancy between the law and the executive order which may be a potential problem in all emerging countries. A major recommendation to the international bodies that may be derived from this paper is to develop indicators to measure the change in the actual practices of the financial accounting systems. Given the complexity of the public sector accounting reforms, special attention should be paid to the adoption and implementation of the standards both by the national and international policy makers. Other suggestions include enhancing the role of national Supreme Audit Institution and linking its activities with the international bodies to better understand what is being executed in the operationalization of the law and the regulations.

Moreover, because non-native English speakers may be less confident in the translation and interpretation of the concepts from English into their native language(s), the importance of translation must be emphasized, with the recognition that good translation is crucial to success. A group of experts working on translating concepts from IPSAS into Turkish or any other language should also link the translation of concepts with their actual practices in order to create a springboard for successful IPSAS adoption.

Finally, our results should be interpreted with caution. This study was based solely on the Central Government Public Account for the 2010-2014 year-end financial reports. In future work, we must further improve our understanding by analyzing the public sector as a whole, including the central government, local governments and social institutions. 


\section{References:}

1. Allen, A. and Sanders, G.D., 'Financial Disclosure in US Municipalities: Has the Governmental Accounting Standards Board Made a Difference?', 1994, Financial Accountability and Management, vol. 10, no. 3, pp. 175-193.

2. Alshujairi, M.H.A., 'Government Accounting System Reform and the Adoption of IPSAS in Iraq', 2014, Research Journal of Finance and Accounting, vol. 5, no. 24, pp. 1-20.

3. Andrews, M., 'The Logical Limits of Best Practice Administrative Solutions in Developing Countries', 2012, Public Administration and Development, vol. 32, no. 2, pp. 137153.

4. Andrews, M., 'Which Organizational Attributes are Amenable to External Reform? An Empirical Study of African Public Financial Management', 2011, International Public Management Journal, vol. 14, no. 2, pp.131-156.

5. Antipova, T. and Bourmistrov, A., 'Is Russian Public Sector Accounting in the Process of Modernization? An Analysis of Accounting Reforms in Russia', 2013, Financial Accountability and Management, vol. 29, no. 4, pp. 442-478.

6. Arnaboldi, M. and Lapsley, I., 'On the Implementation of Accrual Accounting: A Study of Conflict and Ambiguity', 2009, European Accounting Review, vol. 18, no. 4, pp. 809-836.

7. Ashworth, R.E., Boyne, G.A. and Delbridge, R., 'Escape from the Iron Cage? Organizational Change and Isomorphic Pressures in the Public Sector', 2009, Journal of Public Administration Research and Theory, vol. 19, no. 1, pp. 165-187.

8. Atkinson, A.A. and Shaffir, W., 'Standards for Field Research in Management Accounting', 1998, Journal of Management Accounting Research, vol. 10, pp. 41-68.

9. Benito, B., Brusca, I. and Montesinos, V., 'The Harmonization of Government Financial Information Systems: The Role of the IPSASs', 2007, International Review of Administrative Sciences, vol. 73, no. 2, pp. 293-317.

10. Bromley, P. and Powell, W.W., 'From Smoke and Mirrors to Walking the Talk: Decoupling in the Contemporary World', 2012, The Academy of Management Annals, vol. 6, no. 1, pp. 483-530.

11. Christensen, M. and Parker, L., 'Using Ideas to Advance Professions: Public Sector Accrual Accounting', 2010, Financial Accountability and Management, vol. 26, no. 3, pp. 246-266.

12. Christiaens, J., Reyniers, B. and Rollé, C., 'Impact of IPSAS on Reforming Governmental Financial Information Systems: A Comparative Study', 2010, International Review of Administrative Sciences, vol. 76, no. 3, pp. 537-554.

13. Christiaens, J., Vanhee, C., Manes-Rossi, F., Aversano, N. and Van Cauwenberge, P., 'The Effect of IPSAS on Reforming Governmental Financial Reporting: An International Comparison', 2015, International Review of Administrative Sciences, vol. 81, no. 1, pp. 158-177.

14. Connolly, C. and Hyndman, N., 'The Actual Implementation of Accruals Accounting: Caveats from A Case within the UK Public Sector', 2006, Accounting, Auditing \& Accountability Journal, vol. 19 no. 2, pp. 272-90

15. Coy, D. and Dixon, K., 'The Public Accountability Index: Crafting a Parametric Disclosure Index for Annual Reports', 2004, The British Accounting Review, vol. 36, no. 1, pp. 79-106. 
16. Deaconu, A., Nistor, C.F. and Filip, C., 'The Impact of Accrual Accounting on Public Sector Management: An Exploratory Study for Romania', 2011, Transylvanian Review of Administrative Sciences, vol. 32, pp. 74-97.

17. DiMaggio, P.J. and Powell, W.W.,' The Iron Cage Revisited: Collective Rationality and Institutional Isomorphism in Organizational Fields', 1983, American Sociological Review, vol. 48, no. 2, pp. 147-160.

18. DiMaggio, P.J. and Powell, W.W., The New Institutionalism in Organizational Analysis, Chicago: University of Chicago Press, 1991.

19. General Management Accounting Regulation, published in the Official Gazette of Turkey no. 25839 from June 8, 2005.

20. Giroux, G. and McLelland, A.J., 'Governance Structures and Accounting at Large Municipalities', 2003, Journal of Accounting and Public Policy, vol. 22, no. 3, pp. 203-230.

21. Gomes, P.S., Fernandes, M.J. and Carvalho, J.B.D.C., 'The International Harmonization Process of Public Sector Accounting in Portugal: The Perspective of Different Stakeholders', 2015, International Journal of Public Administration, vol. 38, no. 4, pp. 268-281.

22. Hughes, J., 'A Compilation and Certification Program for Developing Countries', 2013, Journal of Governmental Financial Management, vol. 13, no 1, pp. 1-14.

23. International Public Sector Accounting Standards (IPSAS), [Online] available at https://www.ifac.org/publications-resources/2016-handbook-international-public-sector-accounting-pronouncements, accessed on November 28, 2017.

24. Kocacık, F., 'Bilgi toplumu ve Türkiye', 2003, Sosyal Bilimler Dergisi, vol. 27, no. 1, pp. 1-10.

25. Lampe, H.W., Hilgers, D. and Ihl, C., 'Does Accrual Accounting Improve Municipalities' Efficiency? Evidence from Germany', 2015, Applied Economics, vol. 47, no. 41, pp. 4349-4363.

26. Manes Rossi, F., Aversano, N. and Christiaens, J., 'IPSASB's Conceptual Framework: Coherence with Accounting Systems in European Public Administrations', 2014, International Journal of Public Administration, vol. 37, no. 8, pp. 456-465.

27. Marco, J., 'The Terminology of Translation: Epistemological, Conceptual and Intercultural Problems and Their Social Consequence', 2007, Target, vol. 19, no. 2, pp. 255-269.

28. Martí, C. and Kasperskaya, Y., 'Public Financial Management Systems and Countries' Governance: A Cross-Country Study', 2015, Public Administration and Development, vol. 35, no. 3, pp. 165-178.

29. Müftüler Baç, M., 'Turkey's Political Reforms and the Impact of the European Union', 2005, South European Society and Politics, vol. 10, no. 1, pp. 16-30.

30. Nelson, P.J., 'Multilateral Development Banks, Transparency and Corporate Clients: 'Public-Private Partnerships' and Public Access to Information', 2003, Public Administration E Development, vol. 23, no. 3, pp. 249-257.

31. Nor-Aziah, A.K. and Scapens, R.W., 'Corporatization and Accounting Change: The Role of Accounting and Accountants in A Malaysian Public Utility', 2007, Management Accounting Research, vol. 18, no. 2, pp. 209-247.

32. Öniş, Z. and Kutlay, M., 'The Dynamics of Emerging Middle-Power Influence in Regional and Global Governance: The Paradoxical Case of Turkey', Australian Journal of International Affairs, 2017, vol. 71, no. 2, pp. 164-183. 
33. Oulasvirta, L., 'The Reluctance of a Developed Country to Choose International Public Sector Accounting Standards of the IFAC. A Critical Case Study', 2014, Critical Perspectives on Accounting, vol. 25, no. 3, pp. 272-285.

34. Pérez, C.C. and Hernández, A.L., 'Latin-American Public Financial Reporting: Recent and Future Development', 2007, Public Administration and Development, vol. 27, no. 2, pp. 139-157.

35. Pina, V. and Torres, L., 'Reshaping Public Sector Accounting: An International Comparative View', 2003, Canadian Journal of Administrative Sciences Revue, vol. 20, no. 4, pp. 334-350.

36. Pina, V., Torres, L. and Yetano, A., 'Accrual Accounting in EU Local Governments: One Method, Several Approaches', 2009, European Accounting Review, vol. 18, no. 4, pp. 765-807.

37. Public Financial Management and Control Law no. 5018, published in the Official Gazette of Turkey no. 25326 from December 24, 2003.

38. Rahaman, A.S., 'Independent Financial Auditing and the Crusade against Government Sector Financial Mismanagement in Ghana', 2009, Qualitative Research in Accounting and Management, vol. 6, no. 4, pp. 224-246.

39. Ryan, C., Stanley, T. and Nelson, M., 'Accountability Disclosures by Queensland Local Government Councils: 1997-1999', 2002, Financial Accountability and Management, vol. 18, no. 3, pp. 261-289.

40. Sözen, S. and Shaw, I., 'The International Applicability of "New" Public Management: Lessons from Turkey', 2002, International Journal of Public Sector Management, vol. 15, no. 6, pp. 475-486.

41. Tashakkori, A. and Teddlie, C., Mixed Methodology: Combining Qualitative and Quantitative Approaches, Thousand Oaks/London/New Delhi: Sage Publications, 1998.

42. Tooley, S. and Guthrie, J., 'Reporting Performance by New Zealand Secondary Schools: An Analysis of Disclosures', 2007, Financial Accountability and Management, vol. 23, no. 4, pp. 351-374.

43. Torres, L., 'Accounting and Accountability: Recent Developments in Government Financial Information Systems', 2004, Public Administration and Development, vol. 24, no. 5, pp. 447-456.

44. Tudor, A., 'Romanian Public Institutions Financial Statements on the Way of Harmonization with IPSAS', 2010, Accounting and Management Information Systems, vol. 19, no. 2, pp. 422-447.

45. Turkish Central Government Public Account Reports, [Online] available at www.muhasebat.gov.tr, accessed on December 1, 2015.

46. Van Helden, G.J., 'Researching Public Sector Transformation: The Role of Management Accounting', 2005, Financial Accountability and Management, vol. 21, no. 1, pp. 99-133.

47. Weick, K.E., 'Administering Education in Loosely Coupled Schools', 1982, The Phi Delta Kappan, vol. 63, no. 10, pp. 673-676.

48. Yüzyıl, Y., 'Türkiye Idaresinin Yeniden Yapılanması Üzerine Bazı Gözlemler', 1996, Yeni Türkiye, vol. 1, no. 4, pp. 120-126.

49. Zeff, S.A., 'Some Obstacles to Global Financial Reporting Comparability and Convergence at a High Level of Quality', 2007, The British Accounting Review, vol. 39, no. 4, pp. 290-302. 


\begin{tabular}{llllll} 
Formal & \multicolumn{5}{c}{ Material Harmonization } \\
\cline { 2 - 6 } Harmonization & 2010 & 2011 & 2012 & 2013 & 2014 \\
\hline
\end{tabular}

1. Budgetary information

Actual budgetary expenditures and revenues

Modification from original budget

Original budgetary expenditure and revenues

Comparison with the previous year

Functional classification of budget items

Economical classification of budget items

Corporate classification of budget items

Financial classification of budget items

2. Physical Assets

Fixed assets

Assets variation

Intangible assets

Infrastructure assets

3. Depreciation of physical assets

Charges for exercise deprecation

Accumulated depreciation

$\begin{array}{llllll}1 & 1 & 1 & 1 & 1 & 1 \\ 1 & 0 & 0 & 0 & 1 & 1 \\ 1 & 1 & 1 & 1 & 1 & 1 \\ 1 & 0 & 0 & 0 & 0 & 0 \\ 1 & 1 & 1 & 1 & 1 & 1 \\ 1 & 1 & 1 & 1 & 1 & 1 \\ 1 & 1 & 1 & 1 & 1 & 1 \\ 1 & 1 & 1 & 1 & 1 & 1\end{array}$

4. Accounting for borrowing cost

Borrowing amount

Term of each long-term debt

Variation of public borrowing

5. Events occurring after balance date

$\begin{array}{llllll}1 & 1 & 1 & 1 & 1 & 1 \\ 1 & 0 & 0 & 0 & 0 & 0 \\ 0 & 0 & 0 & 0 & 0 & 0 \\ 0 & 0 & 0 & 0 & 0 & 0\end{array}$

6. Statement of accounting policies

7. Any statement of the variation of financial position

8. Contingents

9. Financial leasing operations

10. Statement of financial position disclosed

11. Statement of financial performance disclosed

12. Statement of changes net assets in equity disclosed

$\begin{array}{llllll}1 & 1 & 1 & 1 & 1 & 1 \\ 1 & 1 & 1 & 1 & 1 & 1\end{array}$

13. Statement of cash flow disclosed

14. Disclosure of notes

15. Consolidated financial statements

$\begin{array}{llllll}1 & 1 & 1 & 1 & 1 & 1 \\ 0 & 0 & 0 & 0 & 0 & 0 \\ 0 & 0 & 0 & 0 & 0 & 0 \\ 1 & 0 & 0 & 0 & 0 & 0 \\ 1 & 0 & 0 & 0 & 0 & 0 \\ 1 & 0 & 0 & 0 & 0 & 0 \\ 0 & 0 & 0 & 0 & 0 & 0 \\ 0 & 0 & 0 & 0 & 0 & 0 \\ 1 & 1 & 1 & 1 & 1 & 1 \\ 1 & 1 & 1 & 1 & 1 & 1 \\ 0 & 0 & 0 & 0 & 0 & 0 \\ 0 & 0 & 0 & 0 & 0 & 0 \\ 0 & 0 & 0 & 0 & 0 & 0 \\ 0 & 0 & 0 & 0 & 0 & 0\end{array}$

16. Cost of services, economy, efficiency and effectiveness

Cost of the services

Indicators of efficiency

Indicators of effectiveness

$\begin{array}{llllll}0 & 0 & 0 & 0 & 0 & 0\end{array}$

Indicators of economy

0

0

$\begin{array}{lllll}0 & 0 & 0 & 0 & 0\end{array}$

17. Presentation of notes in an order

Disclosed items

Disclosure level

$\begin{array}{llllll}0 & 0 & 0 & 0 & 0 & 0\end{array}$

$\begin{array}{llllll}1 & 0 & 0 & 0 & 0 & 0\end{array}$

\begin{tabular}{cccccc}
19 & 12 & 12 & 12 & 13 & 13 \\
\hline $58 \%$ & $36 \%$ & $36 \%$ & $36 \%$ & $39 \%$ & $39 \%$ \\
\hline
\end{tabular}




\section{Appendix 2: Interview questions}

\section{Part I: General Overview Regarding the Reform Process}

Question: Turkey began a big public accounting reform in the 1990s that is yet ongoing. Since 2004, the government has been working on a new reform that is moving toward the IPSAS adoption. What do you think about this reform process?

Prompt: Could you please describe me how this implementation process affects your daily operations?

Q: What are the stimuli and the main reasons to carry out this reform?

P: Where do institutional arrangements come from in the first place? What causes them to organize the public sector?

P: What is the role of international and professional bodies?

\section{Part II: Reasons Affecting the Level of Harmonization}

Q: Considering the particular features of the political/administrative system and the actual point of public accounting in Turkey, what kind of obstacles and difficulties may arise during the implementation process?

P: How well do you think the accrual-based standards meet the needs of Turkish public sector?

Q: Does the group/organization that you represent agree with the implementation of accrual accounting in the Turkish public sector context?

P: Could you please walk me through what you experienced in your organization?

Q: Considering the Turkish Central Government Public Reports, what do you think regarding the level of disclosure?

P: What do you think about the non-disclosed items? Which items are the nondisclosed items based on your experience?

Q: What might be the reasons behind the non-disclosed items?

P: Do you have any personal experience with the non-disclosed items?

Q: What do you think of material and formal harmonization?

\section{Part III: Means and Strategies}

Q: In order to be successful in this public accounting change process, what means and strategies should be assured in order to increase the level of harmonization? 